Prekariat - perspektywa katolickiej nauki społecznej, red. J. Mazur OSPPE, ks. Ł. Marczak, Kraków 2017

(Spotkania Naukowe Wykładowców Katolickiej Nauki Społecznej, XIII), s. 23-48.

DOI: http://dx.doi.org/10.15633/9788374385985.03

Krzysztof Wielecki

Uniwersytet Kardynała Stefana Wyszyńskiego w Warszawie

\title{
Prekariat: znaczenie, przyczyny i skutki
}

Pojęcie prekariatu budzi wiele dyskusji. Niektórzy sądzą, iż powoduje ono jedynie jeszcze większe zamieszanie w i tak bardzo już nieczytelnej, przegadanej i mętnej humanistyce, inni zaś wiążą z nim ogromne nadzieje. Nie przesądzając, kto ma rację w tym sporze, warto zrozumieć kontekst pojawienia się tego pojęcia i jego świetnej kariery. Niezależnie od przekonań co do wartości i znaczenia pojęcia prekariatu byłoby ze wszech miar pożyteczne zbadać rzeczywistość, w jakiej się ono pojawia, i rozważyć, czego tradycyjne pojęcia nie określają wystarczająco precyzyjnie, co sprawia, że użytkownicy odczuwają potrzebę owego neologizmu. Być może kategoria prekariat jest bardziej publicystyczna. Jednak publicyści, niezobowiązani do puryzmu terminologicznego, potrafią czasem dostrzec i opisać coś bardzo ważnego, co z powodu wymogów formalnych, oraz być może za sprawą nowości zjawiska, jest nieobecne w akademickim dyskursie. Nie powinniśmy, jak sądzę, obrażać się na to. Nie musimy też wcale przyjmować wszystkiego z „dobrodziejstwem inwentarza”. Należałoby jednak spokojnie przyjrzeć się całemu kontekstowi problemu i wykorzystując naukowy warsztat, rozeznać „materię”, uściślić definicje, zoperacjonalizować je i wkomponować $\mathrm{w}$ dotychczasowy dorobek teoretyczny. Z takim zamiarem przybliżenia się, z konieczności cząstkowego, socjologa do problemu prekariatu został napisany niniejszy artykuł. 
Sądzę, iż zrozumienie realnej rzeczywistości, jaka stanowi tło dyskusji o prekariacie, wymaga szerszego spojrzenia na współczesność. Warto zwłaszcza, jak uważam, wziąć pod uwagę wielkie procesy tzw. długiego trwania, jakie zachodzą w dzisiejszym świecie. Myślę też, że jeśli je obserwować i komentować z osobna, trudno pojąć ich istotę, gdyż ta tkwi właśnie w warstwie wielkich procesów cywilizacyjnych, przełamujących się osobliwie w naszych czasach. Ważny tu wydaje się właśnie ów wymiar cywilizacyjny. W jego kontekście zaś trzeba koniecznie - jak mniemam - rozważyć przemiany ładu społecznego, ze szczególnym uwzględnieniem porządku gospodarczego świata (megastruktur) i makrostruktur społecznych.

\section{Wymiar cywilizacyjny}

Sądzę, że zjawisko prekariatu, jak i istota dyskusji wokół niego ma swoje źródło w procesach cywilizacyjnych ${ }^{1}$. Nie jest to dobra okazja do głębszych rozważań na temat cywilizacji, ale właśnie w procesach cywilizacyjnych widzieć trzeba, jak sądzę, najważniejszy kontekst omawianej kwestii.

Przyjmijmy zatem, że jest to pewien stan społeczny, wynik procesów historycznych długiego trwania, wytwarzany przez społeczeństwa, przekraczający czas życia kilku pokoleń. Cywilizacja tworzy ramy, w których, w niemałym stopniu pod jej wpływem, ludzie konstruują ład społeczny, tworzą grupy i instytucje społeczne, kulturę i swoje tożsamości. Cywilizacja to ogół procesów i wytworów społecznych, jakie powstają w odpowiedzi na kryzys cywilizacyjny. Zmiana cywilizacyjna, zaś - jak proponuję ją rozumieć - to splot procesów o charakterze historycznym, występujących w tym samym czasie i przestrzeni, spowodowanych przez kryzys cywilizacyjny i wyzwania cywilizacyjne ${ }^{2}$. Zgodnie

\footnotetext{
${ }^{1}$ Por. K. Wielecki, Kryzys i socjologia, Warszawa 2012.

${ }^{2}$ K. Wielecki, Kryzys i socjologia, dz. cyt.
} 
ze starogreckim znaczeniem słowa „kryzys” jest to punkt zwrotny, przełom. Wyzwania cywilizacyjne utrudniają lub uniemożliwiają istnienie społeczeństwa bez istotnych zmian, głębokich, długotrwałych, a czasem dramatycznych procesów adaptacyjnych. Czynnikami takiego kryzysu mogą być wielkie wydarzenia historyczne (wojny, rewolucje itp.), zjawiska przyrodnicze (np. powodzie, trzęsienia ziemi) albo przełomowe odkrycia naukowe i techniczne czy nowe religie, idee lub wielkie racjonalizacje, wyobrażenia, mity. Czynniki takie często nie tylko są wyzwaniem dla jakiejś odosobnionej społeczności, lecz mają także znaczenie bardziej uniwersalne. Tradycja zatem wiąże pojęcie cywilizacji z szerszą przestrzenią. Cywilizacje długo powstają i powoli się rozwijają. Zwykle jest to proces, który zachodzi za pamięci więcej niż jednego pokolenia ${ }^{3}$.

W czasach obecnego kryzysu cywilizacyjnego głównym procesem cywilizacyjnym, powodującym wspomniane zmiany cywilizacyjne i naruszającym podstawy równowagi ładu społecznego, jest globalizacja. Rozpoczęła się ona, orientacyjnie rzecz biorąc, w połowie lat siedemdziesiątych, w wyniku skumulowania się wielu odkryć naukowych i technicznych oraz ich coraz bardziej powszechnego wdrażania do praktyki społeczeństwa przemysłowego. Nowe technologie, nie pierwszy raz w historii, zmieniły ludzki świat. W tym wypadku spowodowały schyłek trwającej od osiemnastowiecznej rewolucji naukowo-technicznej cywilizacji industrialnej.

Żeby zrozumieć współczesny kryzys cywilizacyjny, trzeba się cofnąć do dwóch zasadniczych i wzajemnie zależnych procesów cywilizacyjnych: kulturowego i ekonomicznego. Zapoczątkowany pod koniec XVII wieku intelektualny i artystyczny prąd oświecenia przyniósł ufność w siłę ludzkiego rozumu oraz wiarę w postęp i porządek zbudowanego na nim świata. Zdaniem niektórych mentalność oświecenia trwa do dzisiaj, z pięćdziesięcioletnią przerwą na romantyzm. Z oświeceniem wiąże się sięgający renesansu oraz

\footnotetext{
${ }^{3}$ K. Wielecki, Kryzys i socjologia, dz. cyt.
} 
rozpoczętej w XVIII wieku rewolucji naukowo-technicznej proces sekularyzacji. Od XIV wieku rozwijają się różne odmiany kapitalistycznego instrumentarium ekonomicznego. W drugiej połowie XIX wieku procesy te spotykają się, tworząc kapitalistyczne społeczeństwo industrialne.

W industrializmie można wyodrębnić pewne fazy, w których nasilały się lub słabły rozmaite formy kryzysu i w których socjologia w rozmaity sposób, poprzez odmienne orientacje teoretyczne, reagowała na swoje czasy: fazę wczesną - dość brutalnego i gwałtownie przeobrażającego świat industrializmu, sięgającą lat pięćdziesiątych XIX wieku; fazę środkową (1848-1871), kiedy to na krótko sytuacja się stabilizuje; i fazę kapitalizmu monopolistycznego, która kończy się I wojną światową ${ }^{4}$. W Europie Zachodniej i innych państwach demokratycznych można też mówić o czwartej, specyficznej fazie spełnionego lub dojrzałego kapitalizmu (1945-1975).

Jak wspominałem, około połowy lat 70. XX wieku rozpoczął się nowy, trwający do dzisiaj kryzys cywilizacyjny - postindustrialny. Jest on wynikiem zupełnie nowego procesu cywilizacyjnego, zapoczątkowanego w XX wieku nową rewolucją naukowo-techniczną. Powstanie i rozwój takich technologii, jak inżynieria genetyczna, mikroprocesory, automatyzacja i komputeryzacja radykalnie przeobraziły kapitalizm i wytwórczość. Znacznie obniżyły znaczenie pracy ludzkiej, zwłaszcza fizycznej i prostej umysłowej, jak i produkcji przemysłowej, ustanawiając tzw. gospodarkę wiedzy, tworząc jedną globalną sieć komunikacyjną, a zarazem gospodarczą i polityczną. Ogół tych procesów cywilizacyjnych nazywa się globalizacją.

W latach 70. XX wieku następuje w związku z tym załamanie podstaw porządku społecznego późnej fazy industrializmu, a przede wszystkim jego fundamentu ekonomicznego i kulturalnego. Wiele pisze się też o ówczesnym kryzysie ładu instytucjo-

\footnotetext{
${ }^{4}$ Por. W. Kula, Problemy i metody historii gospodarczej, Warszawa 1983.
} 
nalnego, czy wręcz o kryzysie nowoczesnej demokracji liberalnej, oraz o ogromnych przemianach w zakresie struktury społecznej. Przyczyną nie jest jednak głównie wewnętrzny kryzys industrializmu, ponieważ ten akurat został w niemałym stopniu złagodzony przez model gospodarki rynkowej zorientowanej na cele społeczne - podstawowe osiągnięcie spełnionego kapitalizmu. W ramach tego ładu społecznego nowoczesne państwo reprezentowało (przynajmniej do pewnego stopnia) interes wszystkich obywateli, odnajdywało sens w roli mediatora i gwaranta kompromisu między głównymi klasami społecznymi: pracodawców i pracobiorców ${ }^{5}$, zapewniało równowagę międzynarodową gwarantującą pokój (przynajmniej w skali globalnej i tam, gdzie ów porządek funkcjonował). Określam go jako demokratyczno-liberalny ład społeczny oparty na prospołecznej gospodarce rynkowej.

Miał ten ład poważne wady i surowych krytyków. Główne zarzuty dotyczyły ograniczenia demokracji, głównie przez faktyczne zawężanie możliwości wyboru politycznego (w wyniku stabilizowania się systemu partyjnego i upodabniania się programów partii politycznych); ekonomicznych obciążeń systemu państwa dobrobytu w wyniku stosowania tzw. korekty redystrybucyjnej, osłabiania motywacji do pracy i prowadzenia biznesu. Zdarzało się, że ów kompromis bywał zaburzany w drugą stronę, powodując rozwój postaw roszczeniowych.

Warto wspomnieć nieco o powodach tego kryzysu cywilizacyjnego, który naruszył podstawy owego spełnionego kapitalizmu i demokratyczno-liberalnego ładu społecznego opartego na prospołecznej gospodarce rynkowej. Otóż jeszcze w 1979 roku Krajowa Akademia Nauk w Stanach Zjednoczonych ogłaszała, że współczesna era elektroniki „zapoczątkowała drugą rewolucję

${ }^{5}$ J. Habermas, Kryzys państwa dobrobytu i wyczerpywanie się energii utopijnych, „Colloquia Communia” (1986) nr 4-5 (27-28).

6 System podatkowy jest źródłem finansowania polityki społecznej, która częściowo zmniejsza nierówności dochodów i zapewnia każdemu obywatelowi zdolność utrzymania się na poziomie minimum socjalnego. 
przemysłową [...], której znaczenie dla ludzkości może być jeszcze większe niż to, jakie miała pierwsza" ${ }^{7}$. W jednym $\mathrm{z}$ kolejnych Raportów Klubu Rzymskiego, opublikowanym w 1991 roku czytamy zaś:

Tematem spotkań Klubu Rzymskiego była w ostatnim czasie tak zwana wielka przemiana (The Great Transition). Jesteśmy przekonani, że znajdujemy się we wczesnym stadium powstawania nowego typu społeczności świata tak różnej od dzisiejszej, jak społeczności z poprzedzającego ją długiego okresu rolniczego. Początkową, ale bynajmniej nie jedyną siłą napędową tych przemian było pojawienie się kompleksu nowych technologii, szczególnie tych, które powstały dzięki odkryciom mikrotechnologii i biologii molekularnej. Stwarzają one tak zwane społeczeństwo ery informatyki, społeczeństwo postindustrialne albo społeczeństwo usług. Zatrudnienie, styl życia oraz perspektywy materialne i wszelkie inne dla każdego mieszkańca Ziemi bardzo będą się w nim różnić od tych $\mathrm{z}$ dnia dzisiejszego ${ }^{8}$.

Procesy cywilizacyjne wpływają na ład społeczny. Określam go jako stale tworzony, odtwarzany i zmienny wynik dynamicznego, wewnętrznie niejednorodnego, a także złożonego procesu strukturacji. Jest to proces krystalizowania się, reprodukowania, rozpadu i transformacji, relatywnie stałych i względnie ciągłych podstaw organizowania się społecznej praktyki życia w obrębie względnie wyodrębnionej dużej społeczności. Tak pojmowany

${ }^{7}$ National Academy of Sciences - National Research Council, Microstructure Science, Engineering and Technology, Washington 1979; por. A. King, Wstęp: Nowa rewolucja przemystowa czy jeszcze jedna technologia?, w: Mikroelektronika i społeczeństwo: na dobre czy na złe? Raport dla Klubu Rzymskiego, red. nauk. M. Rostocki, red. G. Fredrichs, A. Schaff, tł. zespół, Warszawa 1987, s. 4 .

8 A. King, B. Schneider, Pierwsza rewolucja globalna. Jak przetrwać? Raport Rady Klubu Rzymskiego, tł. W. i S. Rączkowscy, Warszawa 1992, s. 21. 
ład społeczny wyznacza mniej lub bardziej trwałe ramy wspólnej praktyki życia. Wyróżniamy w ładzie społecznym pięć wymiarów: strukturę społeczną (grupy, warstwy i klasy społeczne oraz system zależności między nimi); kulturę, ład instytucjonalny, ład gospodarczy i ład demograficzny.

Procesy zachodzące w trakcie nieustannego strukturyzowania się ładu społecznego są widoczne zwłaszcza na poziomie porządku ekonomicznego. Kryzys dotyka także kapitalizmu. Wyczerpują się tradycyjne źródła akumulacji kapitału. Nasilają się dramatyczne konflikty społeczne, które wpisane są w naturę kapitalizmu, unieważnieniu ulega państwo opiekuńcze, które pojmuję jako historyczny kompromis społeczny. Przez długi czas dobrze służył on głównym klasom społecznym i kapitalizmowi, a zwłaszcza demokracji. W czasach globalnej sieci nie jest to już takie proste.

We współczesnej gospodarce dzisiejszego kryzysu cywilizacyjnego i związanego z nim kryzysu ładu społecznego wyraźnie wyłaniają się dwie orientacje. Pierwszą jest kapitalizm bezwzględny, nastawiony wyłącznie na akumulację kapitału, bez skrupułów wykorzystujący globalną sieć, aby ominąć jakiekolwiek zobowiązania wobec człowieka, kultury, środowiska naturalnego itp. Opiera się on głównie na anonimowym akcjonariacie, bezosobowych przepływach wirtualnego pieniądza, którego właściciele najczęściej nic nie wiedzą o tym, gdzie, po co i na jakich warunkach inwestuje się ich środki finansowe, a tym bardziej nie zamierzają się z kimkolwiek lub czymkolwiek utożsamiać, solidaryzować lub komukolwiek współczuć. Kapitalizm taki bez żenady niszczy ludzi, środowisko i kulturę. Jego zwolennicy posługując się ideologią neoliberalnej wolności, monopolizują rynek, niszczą konkurencję. Odpersonalizowanie kapitału i jego obrotu powoduje, że nikt konkretnie nie czuje się odpowiedzialny, zobowiązany lub winny. Winne są jakieś bezosobowe, obiektywne siły, może porządek rzeczy, na którym można zarobić, ale któremu nie można się przeciwstawić. To jest jakaś nowa, XXI-wieczna forma alienacji. Drugą orientacją jest kapitalizm o bardziej korporacyjnym 
nastawieniu (zapewne najbardziej zaawansowany w Szwecji), występujący między innymi w postaci ruchów społecznych lub wspólnot. Zysk, choć bardzo ważny, nie jest dla niego jedynym dobrem, proces decyzyjny i redystrybucja zysku ma często cele społeczne lub ekologiczne. Procesy ekonomiczne są bardziej spersonalizowane, często mają charakter wspólnotowy. Wydaje się jednak, iż procesy globalizacji bardziej sprzyjają temu pierwszemu rodzajowi kapitalizmu.

Nowa cywilizacja powoduje także ogromne zmiany w zakresie struktury społecznej i ładu instytucjonalnego. Struktura klasowa oparta na stosunkach między pracodawcami i pracobiorcami oraz na idei równowagi między nimi przechodzi do historii. Jej fundament, historyczny kompromis welfare state, stracił swoją podstawę w równowadze sił między pracodawcami i pracobiorcami. Pozycja tych ostatnich uległa ogromnemu osłabieniu w wyniku rozwoju technologii wypierających pracę ludzką. Komputeryzacja, miniaturyzacja i automatyzacja sprawiły, iż pracodawcy przestali być tak zależni od pracobiorców jak dawniej. Wraz z rozwojem cywilizacji, a zwłaszcza postępem w dziedzinie nowych technologii, podstawy nowoczesnego ładu społecznego opartego na zasadach demokratyczno-liberalnych oraz logice państwa dobrobytu i państwa opiekuńczego są coraz bardziej chwiejne.

Państwo, które wcześniej było mediatorem i gwarantem strategicznego kompromisu między pracobiorcami i pracodawcami, ma zatem z jednej strony partnera (pracobiorców), którego znaczenie jest dziś już stosunkowo małe i coraz mniejsze, oraz partnera, który jest coraz silniejszy, jednak, po pierwsze - często trudny do zidentyfikowania, a po drugie, w związku z tworzeniem się rynku globalnego o wysokim stopniu wolności, słabo podlega jurysdykcji i mechanizmom kontroli oraz nacisku pojedynczych państw. Nierzadko państwo jest słabsze od korporacji, która działa na jego terenie. Jak więc może wywiązać się ze swej roli mediatora i gwaranta historycznego kompromisu społecznego i ekonomicznego? 
Ten kompromis przeciął tragiczny wątek blisko dwustuletniej historii kapitalizmu. Zanim do niego doszło, przez świat (zwłaszcza Europę) przeszła fala rewolucji, wojen i zapaści gospodarczych. Nie był prezentem, tylko mądrością, ciężko okupioną krwią i niedolą milionów. Wolny rynek to utopia, która już raz się nie sprawdziła. Nigdzie. Bo nigdzie do dziś nie istnieje 9 . Gdy stwierdzamy, że pozycja pracobiorców słabnie, to musimy pamiętać, iż proces ten dotyczy także ogromnej części tzw. klasy średniej. Jest to o tyle niebezpieczne, iż uważa się ją często za czynnik stabilizujący demokrację. Nowoczesne technologie wkraczają także w tradycyjne obszary tzw. pracy umysłowej. Jednak szczególnej uwagi warta jest stale rosnąca rzesza tych, którzy nie mają i nie będą mieli pracy. Ich bezrobocie będzie miało, zapewne w dużej mierze, charakter dziedziczny.

Naturalnie to scenariusz pesymistyczny. Być może, jak obiecują niektórzy, pojawią się nowe miejsca pracy, właśnie dzięki sektorowi nowoczesnych technologii, być może powstanie nowoczesne, globalne społeczeństwo obywatelskie, poważny partner globalnego kapitału. Być może będzie jeszcze inaczej. Nie sposób nie zauważyć, iż nowe czasy oferują ludziom nowe możliwości życia wygodniejszego, bezpieczniejszego, bardziej odpowiadającego ich potrzebom indywidualnym, dającego jednostce więcej wolności.

\section{Pojęcie prekariatu}

Pojęcie prekariatu nie jest zupełnie nowe w literaturze naukowej. Spotkać je można było w pracach tak wybitnych uczonych, jak Michel Foucault, Pierre Bourdieu czy Jürgen Habermas. Jednak największe powodzenie zapewnił mu Guy Standing, a to dzięki opublikowanej w 2011 roku książce The Precariat: The New

${ }^{9} \mathrm{~K}$. Wielecki, Globalisation and Free Market - from the Perspective of Sociology of Europe, „Yearbook of Polish European Studies” (2004) t. 8. 
Dangerous Class $^{10}$. Swoje idee autor rozwija też w innych publikacjach, a zwłaszcza w pracach: A precariat charter: From denizens to citizens ${ }^{11}$ oraz Basic income: A transformative policy for India $^{12}$. W Polsce ukazała się także książka pt. Karta prekariatu ${ }^{13}$.

Główną myślą autora jest idea, że w warunkach dzisiejszego kapitalizmu wyodrębnia się nowa klasa społeczna. Jednak trzeba to rozumieć w innym sensie niż koncept Karola Marksa, Maxa Webera, Gaetana Mosciego lub Pierre’a Bourdieu ${ }^{14}$. Nie będziemy tu wchodzili w zagadnienia teorii struktury społecznej. Powiedzmy tyle, iż Standing rozważa inną jej koncepcję. Jeśli dobrze rozumiem, wyróżnia on fenomenologicznie sześć klas we współczesnych globalizujących się społeczeństwach. Stąd tradycyjne pojmowanie klasy społecznej jako części społeczeństwa narodowego nic tu nie da. Być może trafniej byłoby się odwołać do pojęcia rzeszy u Antonia Negriego i Michaela Hardta ${ }^{15}$.

Pojęcie precariat zbudowane jest $\mathrm{z}$ dwóch słów: precarious (niepewny) i proletariat (klasa pracująca). Pewność odnosi się tu do

pewności, z jaką zatrudnienie może być utrzymane w dłuższym czasie, stopnia kontroli nad warunkami pracy, stopnia ochrony miejsca i warunków pracy przez stosowane przepisy oraz możliwość dochodzenia swoich praw i wysokość zarobków. W rozmaite charakterystyki i sposoby pomiaru prekaryjności wbudowuje się szereg cech dodatkowych, takich jak pozapłacowe świadczenia pracownicze, autonomię w wykony-

${ }^{10}$ G. Standing, Prekariat. Nowa niebezpieczna klasa, tł. Warszawa 2016.

11 G. Standing, A precariat charter: From denizens to citizens, London 2014.

12 G. Standing, Basic income: A transformative policy for India, London-New Delhi 2015.

13 G. Standing, Karta prekariatu, tł. P. Juskowiak, P. Kaczmarski, M. Szlinder, Warszawa 2015.

${ }^{14}$ Więcej na ten temat w: A. Kolek, „Prekariat” jako nowa klasa społeczna. Geneza, istota, wyzwania, http://publikacje.ils.uw.edu.pl/handle/123456789/3301 (21.10.2015).

15 A. Negri, M. Hardt, Imperium, tł. S. Ślusarski, Warszawa 2005. 
waniu zadań w pracy, zgodność zatrudnienia z kwalifikacjami, bezpieczeństwo fizyczne i warunki zdrowotne, czy możliwość godzenia pracy zawodowej i życia ${ }^{16}$.

Zatem rzecz nie tylko w tym, czy istnieje warstwa (lub klasa) społeczna ludzi bez pracy czy zagrożona bezrobociem; idzie także o stan swoistego wykluczenia społecznego. Jak pisze sam Standing, prekariusze to ludzie, którzy

wykonują zajęcia nieznane tradycji społecznej, bez poczucia przynależności do społeczności zawodowej opartej na stałych praktykach, kodeksach etycznych oraz normach zachowań, wzajemności i braterstwa. Prekariuszki i prekariusze nie czują się częścią solidarnej społeczności pracowniczej, co sprawia, że funkcjonują w poczuciu alienacji i instrumentalnego traktowania ${ }^{17}$.

Mamy zatem do czynienia $\mathrm{z}$ nowym rodzajem alienacji przez pracę $\mathrm{w}$ warunkach globalizacji.

Niepewność i wyobcowanie miałoby być istotą omawianego zjawiska. Jak pisze Katarzyna Cymbrianowicz:

według Standinga prekariusz to proletariusz XXI w., czyli osoba, która funkcjonuje w warunkach ciągłej niepewności. Niepewność, o której pisze, nie ma charakteru jednowymiarowego. Wręcz przeciwnie, wyraża się ona w charakterystycznych dla prekariatu postawach, tzw. „4a” (ang. anger, anomie, anxiety, alienation $)^{18}$.

16 P. Poławski, Generacja prekariuszy na polskim rynku pracy, „Polityka Społeczna" (2012) nr 9, s. 16.

17 G. Standing, Prekariat..., dz. cyt., s. 52-53.

${ }^{18}$ K. Cymbrianowicz, Prekariat - nowe zjawisko na rynku pracy w Polsce, w: Annales. Etyka w życiu gospodarczym, „Annales. Ethics in Economic Life” vol. 19 (2015) No. 2, s. 20. 
Widzimy zatem, że pojęcie prekariatu wykracza daleko poza problem bezrobocia lub biedy, choć ściśle wiąże się z tymi zjawiskami. Chodzi zatem, jak się zdaje, o warstwę lub klasę społeczną. Ale nie wyłania się ona ze struktury społeczeństwa państwa narodowego, nie jest zatem (lub nie jest przede wszystkim) fragmentem makrostruktur, ale jest raczej efektem globalizacji, a zatem komponentem megastruktury społecznej ${ }^{19}$. Jak wspominałem, rozważam znaczenie pojęcia prekariatu w kontekście zmiany cywilizacyjnej i kryzysu cywilizacji industrialnej.

Chodzi tu także, jak się wydaje, o kategorię ludzi, którzy źle się czują w swoim świecie, czują się wyobcowani, „poza”, bez wpływu na swoje społeczeństwo i własny los. Główną przyczyną, jak rozumiem, jest brak pracy albo praca niestała, źle płatna, bez perspektyw, nieważna społecznie. Jak się zdaje, stan taki powoduje w prekariacie brak poczucia bezpieczeństwa, własnej wartości i podmiotowości oraz sensu świata i znaczenia własnego życia. Nie będę się tu zajmował wartością teoretyczną pojęcia tak szeroko zakreślonego i tak nieprecyzyjnego ani ewentualnymi korespondencjami z istniejącymi teoriami klas lub struktury społecznej. Jak bowiem wspominałem - inny jest cel tego artykułu.

Standing wyróżnia trzy wymiary definicji prekariatu. Pierwszy, jak pisze, „to fakt, że prekariat ma szczególne stosunki produkcji. To grupa, która zmuszona jest do pogodzenia się z niestabilnym zatrudnieniem. Oprócz tego grupie tej brakuje tożsamości zawodowej i nie jest ona zdolna do nadania swojemu życiu jakiejś narracji zawodowej”20. Autor wiąże też prekariat z pracą poniżej posiadanego wykształcenia. Co jest zastanawiające, nie wiemy, czy

19 Kwestię rozróżnień między mega- i makrostrukturą porusza Z. Zagórski, Model wielowariantowego ujmowania rzeczywistości społecznej a perspektywa badań nad wspólnotami cywilizacyjnymi, w: Cywilizacje w perspektywie socjologicznej. Stan i kierunki badań nas cywilizacjami współczesnego świata, red. P. Pieńkowski, Z. Zagórski, Wrocław 2014, oraz (Nie)tad a problem (od)budowy cywilizacji, red. Z. Zagórski, S. Kamykowski, Wrocław 2016.

${ }^{20}$ G. Standing, Rozmowa $z$ Ewą Koszowską. Bezwarunkowy dochód podstawowy. Prof. Guy Standing: każdemu się należy, http://wiadomosci.wp.pl/ 
gdy ktoś pracuje na tzw. umowę śmieciową i spełnia inne warunki, jakie stawia prekariatowi Standing, ale wykonuje czynności zgodne z wykształceniem, to należy do tej klasy, czy nie? Klasa ta, zgodnie z orzeczeniem brytyjskiego ekonomisty, „jest wyzyskiwana także poza godzinami pracy zawodowej" ${ }^{21}$.

Drugi wymiar prekariatu, jak wyjaśnia Standing, sprowadza się do „szczególnych stosunków dystrybucji”. Prekariat mianowicie „musi polegać na wpływie z zarobków, płac, a nie ma dostępu do świadczeń, takich jak emerytury, świadczenia chorobowe itp." ${ }^{22}$. Autor zwraca także uwagę na trzeci wymiar - wymiar relacji z państwem. Jak mówi:

Otóż po raz pierwszy w historii mamy do czynienia z grupą, która zamiast zyskiwać prawa polityczne czy socjalne - traci je. Partie prawicowe troszczą się o swoją klasę średnią, na którą składa się salariat i profesjonicy, a także część plutokracji, którą chcą utrzymać. Partie socjaldemokratyczne natomiast dbają o swoją klasę średnią, składającą się z dolnych szczebli salariatu i proletariatu wraz z liberalnymi członkami elit ${ }^{23}$.

W ten sposób przechodzimy do kwestii struktury klasowej współczesnych społeczeństw i miejsca, w którym znajduje się prekariat. Standing najwyraźniej ma intencję rozwijania nowej teorii struktury społecznej. Mówi autor: „Ważne jest zrozumienie tego, że klasę można zdefiniować w odniesieniu tylko do innych istniejących w społeczeństwie klas. I tematem pierwszej książki Prekariat było pokazanie, że jest taka nowa klasa, nowa struktura

kat,141202,title,Bezwarunkowy-dochod-podstawowy-Prof-Guy-Standing-kazdemu-sie-nalezy,wid,17923766,martykul.html (21.10. 2015).

${ }^{21}$ G. Standing, Rozmowa z Ewą Koszowską. Bezwarunkowy dochód podstawowy..., dz. cyt.

${ }^{22}$ G. Standing, Rozmowa z Ewa Koszowska. Bezwarunkowy dochód podstawowy..., dz. cyt.

${ }^{23}$ G. Standing, Rozmowa z Ewą Koszowska. Bezwarunkowy dochód podstawowy..., dz. cyt. 
klasowa, kształtująca się w wyniku globalizacji i wyłonienia się rynku globalnego"24.

Klasyfikacja Standinga składa się z sześciu kategorii.

Na szczycie hierarchii stoi plutokracja, czyli nie ten 1 proc. najbogatszych, ale 0,01 proc. najbogatszych. Istnieją setki osób, które dysponują kapitałem rzędu nie miliarda dolarów, ale 20-40 miliardów dolarów, a na szczycie tej grupy są osoby zarządzające 80-90 miliardami dolarów! To grupa społeczna, która żyje w całkowicie innym wymiarze niż my. Dysponują ogromną mocą, ogromną potęgą, możliwością wpływania na media, sponsorowania polityki prawicowej, kupowania partii politycznych. Takie firmy jak Goldman Sachs to instytucje plutokratyczne, podobne do nich są chociażby Apple czy IBM, które kontrolują ogromne pieniądze, miliardy dolarów ${ }^{25}$.

Grafika na stronie obok prezentuje prawa klas społecznych ${ }^{26}$. Zaraz za plutokracją mieścić się mają „profesjonicy”. Jak stwierdza Standing, to jest „elita, która cieszy się dużymi zyskami kapitałowymi”27. Poniżej znajduje się „salariat”, który charakteryzuje się „stałym zatrudnieniem, wysokimi pensjami, dostępem do zysków z kapitału, różnego rodzaju świadczeniami, emeryturami itd." ${ }^{28}$. Jeszcze niżej, zdaniem Standinga, odnaleźć można „proletariat", klasę zanikającą w naszych czasach. Znacznie gorszą pozycję w strukturze społecznej ma mieć omawiany tu prekariat jako

${ }^{24}$ G. Standing, Rozmowa z Ewa Koszowska.. Bezwarunkowy dochód podstawowy..., dz. cyt.

${ }^{25}$ G. Standing, Rozmowa $z$ Ewą Koszowską. Bezwarunkowy dochód podstawowy..., dz.cyt.

${ }^{26}$ G. Standing, Rozmowa $z$ Ewą Koszowską. Bezwarunkowy dochód podstawowy..., dz.cyt.

${ }^{27}$ G. Standing, Rozmowa $z$ Ewą Koszowską. Bezwarunkowy dochód podstawowy..., dz.cyt.

${ }^{28}$ G. Standing, Rozmowa $z$ Ewą Koszowska. Bezwarunkowy dochód podstawowy..., dz. cyt. 


\section{PRAWA KLAS SPOKECZNYCH}

\begin{tabular}{|c|c|c|c|c|c|}
\hline \multirow[b]{2}{*}{ klasa } & \multicolumn{5}{|c|}{ prawa } \\
\hline & $\bigoplus_{\substack{\text { osobiste } \\
\text { Ai_ }}}$ & $\underset{\text { polityczne }}{2}$ & $\begin{array}{l}\text { kulturalne } \\
\text { ii. }\end{array}$ & $\begin{array}{c}\text { iit } \\
\text { społeczne }\end{array}$ & $\underset{\text { ekonomiczne }}{\text { it. }}$ \\
\hline PLUTOKRACJA elito & (x) & (x) & $\otimes$ & $\mathrm{O}$ & (४) \\
\hline PROFESIONICY & $\otimes$ & (凶) & $\otimes$ & $\otimes$ & (凶) \\
\hline SALARIAT & (x) & (X) & (x) & (X) & $\otimes$ \\
\hline TRZON KLASY ROBOTNICZE & (凶) & (凶) & $\otimes$ & (凶) & $\otimes$ \\
\hline PREKARIAT & $\otimes$ & (2) & $\otimes$ & (2) & $\ominus$ \\
\hline LUMPENPREKARIAT & $\odot$ & $\odot$ & $\Theta$ & $\Theta$ & $\odot$ \\
\hline$($ sine $\otimes$ średnie & $\otimes$ stabe & (2) watpliwe, & takowane & $\bigodot$ nieobecne & O zbędne \\
\hline
\end{tabular}

nowa, dopiero wyłaniająca się ze społeczeństwa klasa społeczna. Na samym dnie tej piramidy autor lokuje „lumpenprekariat”, czyli ludzi, którzy są „odizolowani od społeczeństwa, cierpiący na różnego rodzaje schorzenia psychiczne, bezdomni, wyizolowani”29.

\section{Prekariat w społeczeństwie kryzysu cywilizacyjnego}

Nie rozważam tutaj teoretycznej wartości pojęcia prekariatu i jego stosunku do istniejących już teorii struktury społecznej, klas społecznych, biedy czy bezrobocia. Próbuję jedynie szkicowo zrekonstruować jego znaczenie $\mathrm{w}$ tekstach, których autorzy $\mathrm{z}$ pełną powagą i przekonaniem je stosują. W szczególności chodzi mi

${ }^{29}$ G. Standing, Rozmowa $z$ Ewą Koszowską. Bezwarunkowy dochód podstawowy..., dz. cyt. 
o znaczenie, które nadaje mu Standing. Obecnie będę raczej starał się odpowiedzieć na pytanie, czy zjawiska objęte definicją prekariatu istnieją we współczesnym świecie i - ewentualnie - jaki jest ich zakres. Pozwoli to, jak mam nadzieję, odpowiedzieć na pytanie, czy warto podejmować teoretyczny trud rozważania definicji prekariatu i budowania jakiejś jego teorii lub redefiniowania teorii już istniejących.

Interesować mnie będą na początek rozmiary biedy i rozwarstwienia społecznego. Jak bowiem się dowiedzieliśmy, to wśród ludzi biednych i wyobcowanych powinniśmy szukać prekariatu i lumpenprekariatu. Warto też zorientować się, jak wielkie różnice w dochodach dzielą poszczególne „klasy” społeczne. Lester Thurow twierdzi, że „rozwarstwienia społeczne są także ważnym kryterium analizy systemu gospodarczego i ładu społecznego". Wyjaśnia, iż „90 proc. zysków z giełdy trafia w USA do 10 proc. najbogatszych gospodarstw domowych, a 60 proc. $z$ nich nie ma żadnych akcji”30. Hipotezę o ogromnych i rosnących dysproporcjach dochodowych potwierdzają badania Oxfam, w którego raporcie czytamy, że

majątek zgromadzony przez 85 najbogatszych ludzi na świecie jest wart tyle, ile posiada 3,5 mld najbiedniejszych, stanowiących połowę ludności świata [...], a łączny majątek 85 najbogatszych ludzi w świecie wynosi 1,7 biliona USD. Ogółem 1 proc. ludności świata zgromadził bogactwo szacowane na 110 bln USD. [...] 70 proc.. ludności świata żyje w krajach, w których przepaść między najbogatszymi i najbiedniejszymi pogłębiła się w ostatnich 30 latach $^{31}$.

Wydaje się zatem, że mamy w dzisiejszych czasach do czynienia z nowym procesem, bardzo wyraźnym i drastycznym.

30 L. C. Thurow, Boom That Wasn't, „New York Times”, 18.01.1999, p. A 19.

3185 najbogatszych ma tyle pieniędzy, co połowa świata, http://www.forbes.pl/ 85-najbogatszych-ma-tyle-pieniedzy-co-polowa-swiata,artykuly,169784,1,1. html (21.10.2015). Tłumaczenie własne, K. W. 
Potwierdza tę sugestię Jeffrey Sachs, który w pracy The Price of Civilization: Reawakening American Virtue and Prosperity, pisze:

Gospodarka coraz wyraźniej służy jedynie wąskiej części społeczeństwa, a mechanizm polityczny nie potrafi wrócić na drogę uczciwego, otwartego i transparentnego rozwiązywania problemów. Zbyt wielu spośród elity - polityków, ludzi bogatych, szefów firm i moich kolegów uniwersyteckich - zapomniało o społecznej odpowiedzialności. Podążają za bogactwem, a resztę niech trafi szlag ${ }^{32}$.

Stan taki, obok oczywistych skutków społecznych, ma także ogromne znaczenie ekonomiczne. Joseph Stiglitz uważa, że niski wzrost wynagrodzeń będzie powodował negatywne rezultaty, gdy chodzi o wzrost gospodarczy. Chodzi oczywiście o wynagrodzenia w biedniejszych segmentach struktury społecznej. Twierdzi on także, że kluczem do zrozumienia amerykańskiej słabej dynamiki wzrostu gospodarczego są nierówności społeczne: „W Stanach Zjednoczonych w okresie 2009-2012 r. 95 proc. zysków trafiło do 1 proc. populacji. Zwykli Amerykanie są zmuszeni do korzystania z oszczędności”33. Chodzi tu oczywiście o popyt konsumpcyjny, który w wypadku niskich wynagrodzeń większości społeczeństwa uniemożliwia pobudzenie gospodarki.

Jak pisze Magdalena Krukowska:

problem, o którym mówi Stiglitz, dotyczy nie tylko amerykańskiej gospodarki. W marcu tego roku Międzynarodowy Fundusz Walutowy (IMF) opublikował wyniki badań swoich

${ }^{32}$ Cyt. za: P. Zalewski, Kapitalizm da się naprawić, ale który?, http://www. forbes.pl/kapitalizm-do-naprawy-co-zrobic-z-nierownowaga-dochodow,artykuly,199264,1,2.html (20.11.2016).

${ }^{33}$ Cyt. za: M. Krukowska, Nierówności hamuja wzrost? http://csr.forbes.pl/ nierownosci-spoleczne-hamuja-wzrost-ospodarczy,artykuly,179424,1,1.html (07.07.2014). 
ekonomistów Jonathana Ostry, Andrew Berga i Charalambosa Tsangarides, z których wynika, że zarówno w średnim, jak i długim okresie nierówności społeczne (mierzone współczynnikiem Giniego) mają destrukcyjny wpływ na wzrost Produktu Krajowego Brutto" ${ }^{\text {. }}$. Natomiast według raportu OECD, „średnie dochody do dyspozycji gospodarstw domowych na całym świecie od czterech lat nie rosną, a dochody najbiedniejszych 10 proc. ludności spadły o 1,6 proc. między 2007 a 2011 r. (okres, który był objęty analizą). USA są krajem wysoko rozwiniętym o największych rozpiętościach dochodowych. Współczynnik Giniego w 2013 r. sięgnął tam 0,42. Podobnie „nierówne” są tylko: Meksyk, Chile i Turcja. Według amerykańskiego Kongresowego Biura Budżetowego nierówności w USA są teraz dużo wyższe niż na początku XX w. ${ }^{35}$

Nie bardzo można się spodziewać poprawy tej kiepskiej sytuacji, bowiem - jak dowiadujemy się z raportu Międzynarodowej Organizacji Pracy w 2016 roku, na świecie (głównie w Azji, Ameryce Łacińskiej i na Bliskim Wschodzie) będzie o ok. 2,3 mln bezrobotnych więcej. W 2017 roku dojdzie do tego kolejne 1,1 mln osób bez pracy, co w efekcie sprawi, że po raz pierwszy w historii naszego globu przekroczymy liczbę $200 \mathrm{mln}$ bezrobotnych ${ }^{36}$.

Jak pamiętamy, prekariat tworzyć mają nie tylko osoby bezrobotne, ale też zatrudnione, tyle że w sposób nieregularny lub za marną płacę. Jak dowiadujemy się z raportu MOP:

na rynkach wschodzących i rozwijających się około $156 \mathrm{mln}$ pracujących osób w wieku 15 do 24 lat musi wyżyć za mniej niż

${ }^{34}$ M. Krukowska, Nierówności hamują wzrost?, dz. cyt.

${ }^{35}$ M. Krukowska, Nierówności hamują wzrost?, dz.cyt.

${ }^{36}$ Bezrobocie na świecie. W ciąu dwóch lat przybędzie 3,4 mln ludzi bez pra$c y$, http://www.money.pl/gospodarka/wiadomosci/artykul/bezrobocie-na-swiecie-w-ciagu-dwoch-lat,224,0,2001632.html (20.01.2016). 


\section{Stopa bezrobocia w krajach Unii Europejskiej w sierpniu}

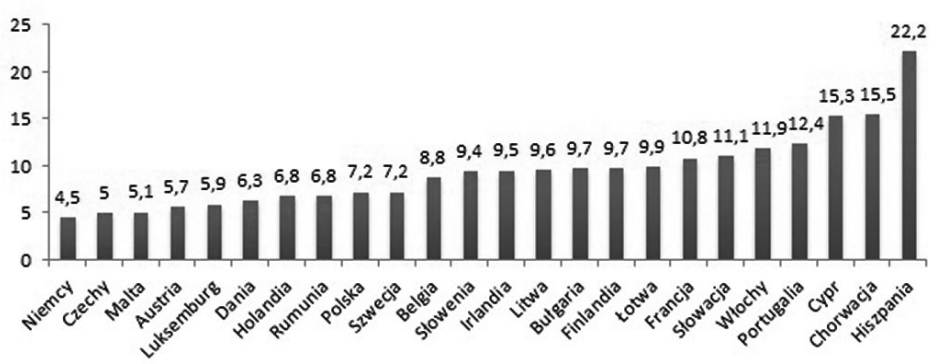

Źródło: money.pl, na podstawie danych Eurostat*. Dane z 2015 roku.

${ }^{*}$ P. Ławrowski, Bezrobocie w UE. Zobacz, w którym kraju jest najwyższe, http://www.money. $\mathrm{pl} /$ gospodarka/unia-europejska/wiadomosci/artykul/bezrobocie-w-ue-zobacz-w-ktorymkraju-jest,146,0,1916562.html (30.09.2015).

3,10 dol. na dzień (około 12 zł). Oznacza to, że około 37 proc. pracujących młodych na świecie żyje w ubóstwie. Dla porównania, w przypadku pracujących dorosłych jest to 26 proc. W wysoko rozwiniętych gospodarkach w zeszłym roku bez pracy pozostawało 9,8 mln osób w wieku 15-24 lata, a stopa bezrobocia wśród młodych wynosiła 14,5 proc. i była wyższa niż w grupie państw o średnim i niskim dochodzie - wynika z raportu MOP. Nie oznacza to jednak, że w biedniejszych państwach panują lepsze warunki na rynku pracy. [...] młodzi ludzie często muszą pracować - zwykle na najprostszych i nisko opłacanych stanowiskach - by zaspokoić podstawowe potrzeby swoich rodzin ${ }^{37}$.

Jak widać, ta ogólnie zła sytuacja szczególnie odbija się na warunkach życia młodej generacji. To ona, zdaje się, przede wszystkim zasila szeregi prekariatu.

${ }^{37}$ Bezrobocie i ubóstwo. Alarmujące dane o sytuacji młodych na świecie, http:// forsal.pl/artykuly/971552,bezrobocie-i-ubostwo-alarmujace-dane-o-sytuacji-mlodych-na-swiecie.html (20.11.2016). 
More Mature, More Unemployment?

Youth joblessness higher in developed economies

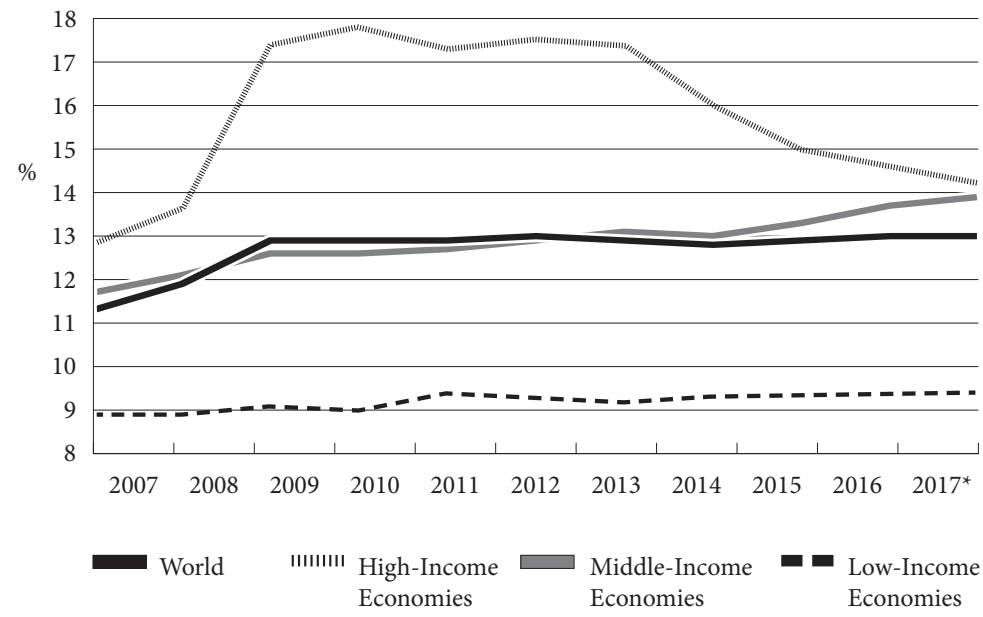

Source: International Labor Organization

* estimated figure

\section{Wnioski}

Poważne konkluzje powinny być poprzedzone przez duże, szeroko zakrojone badania. Nie mam takich możliwości. Zebrane dane zastane potwierdzają jednak bardzo wyraźnie, iż żyjemy w czasach szczególnych, które określiłem jako kryzys cywilizacyjny. Wpływa on na cały ład społeczny, w tym również - jak się okazuje - na ład gospodarczy i strukturę społeczną.

Jakie są mechanizmy wspomnianego kryzysu? Jeden z nich wskazuje Jeremy Rifkin, kiedy pisze:

praktycznie w każdej działalności wytwórczej siłę roboczą stale zastępują maszyny. Miliony ludzi pracy na całym świecie znalazły się w pułapce między dwoma erami gospodarczymi, a nowa, obywająca się bez ludzi technologia spycha ich na margines życia. W pierwszych dekadach XXI wieku robotnik 
w niebieskim kombinezonie przejdzie do historii jako ofiara trzeciej rewolucji przemysłowej i nieubłaganego przymusu osiągania coraz większej sprawności technicznej ${ }^{38}$.

Obawy Rifkina podziela inny ekonomista, Tyler Cowen, który w wywiadzie dla agencji Europejskiego Funduszu Energii mówi:

proces automatyzacji i rozwój handlu globalnego sprawiają, że wzrost nierówności ekonomicznych i kurczenie się klasy średniej w krajach bogatych to nieodwracalny proces. [...] Oszukujemy się, jeśli sądzimy, że na krótką metę możemy proces ten odwrócić; to jedna $\mathrm{z}$ iluzji naszych czasów ${ }^{39}$.

Autor notatki na ten temat, sygnowanej jedynie inicjałami, pisze zaś:

uważany w Stanach Zjednoczonych za umiarkowanego liberała profesor ekonomii na Uniwersytecie George Mason w Wirginii zaliczany jest do najbardziej wpływowych amerykańskich ekonomistów. Zwraca on uwagę na fakt, że od początku tego stulecia dochody amerykańskiej klasy średniej stoją w miejscu. „Od jednego pokolenia w Stanach Zjednoczonych przeciętna rodzina zaliczająca się do klasy średniej zarabia dziś tyle samo co w 1999 roku" wyjaśnia w wywiadzie 51-letni profesor Tyler Cowen, autor wydanej w 2013 roku słynnej w Ameryce książki Average is over ('średnia się skończyła'). Cowen wymienia takie giganty, jak Apple, Google, Facebook, które nie muszą zatrudniać wielkiej liczby ludzi i pokazują, jak „nacisk ekonomiczny

${ }^{38}$ J. Rifkin, Koniec pracy. Schyłek siły roboczej na świecie i początek ery postrynkowej, tł. E. Kania, Wrocław 2003, s. 183.

39 Cyt. za: Adriana C., Nadchodzi epoka nierówności społecznych, http://tvn24bis.pl/ze-swiata,75/klasa-srednia-kurczy-sie-do-tego-rosna-nierownosci-ekonomiczne,515601.html (16.02. 2015). 
postępów technologii, który przyczynia się do wzrostu gospodarczego, eliminuje z rynku klasy średnie" ${ }^{30}$.

Rifkin, autor książek: Koniec pracy. Schyłek siły roboczej na świecie i początek ery postrynkowej ${ }^{41}$, Wiek dostępu. Nowa kultura hiperkapitalizmu, w której płaci się za każda chwile życia ${ }^{42}$, a także Europejskie marzenie. Jak europejska wizja przyszłości zaćmiewa American Dream ${ }^{43}$, stawia tezę o zmianie natury systemu kapitalistycznego. Ma się on obecnie charakteryzować przejściem od produkcji dóbr przemysłowych do produkcji dóbr kultury, komercjalizacją zabawy, komercjalizacją przeżyć, czego skutkiem ubocznym staje się proces przejmowania przez komercję od kultury treści zabawy, rozrywki i przeżywania. Istota tych nowych technologii polega na tym, że ich produkty i usługi wymagają coraz mniej ludzkiej pracy. Mówi autor:

najtańsza siła robocza nigdy nie będzie tak tania jak praca inteligentnych maszyn. W połowie wieku będziemy w stanie zaspokoić całe zapotrzebowanie na dobra i usługi, używając najwyżej 5 proc. ludzkiej siły roboczej. W przemyśle już to widać. W latach 60. co trzeci Amerykanin był pracownikiem przemysłu. Teraz jest co szósty. A produkujemy nieporównanie więcej. Peter Drucker [amerykański filozof i politolog, wybitny teoretyk zarządzania - red.] uważa, że w ciągu dekady zatrudnienie w amerykańskim przemyśle spadnie do 10 proc. $^{44}$

${ }^{40}$ Cyt. za: tamże.

${ }^{41}$ J. Rifkin, Koniec pracy..., dz. cyt.

${ }^{42}$ J. Rifkin, Wiek dostępu. Nowa kultura hiperkapitalizmu, w której płaci się za każdą chwile życia, Wrocław 2003.

${ }^{43}$ J. Rifkin, Europejskie marzenie. Jak europejska wizja przyszłości zaćmiewa American Dream, Warszawa 2005.

${ }^{44}$ Globalny fajrant. Z Jeremim Rifkinem rozmawia Jacek Żakowski, http://kasakobiet.most.org.pl/teksty/globalny_fajrant.html (28.12.2001). 
Dziś nawet najtańsza siła robocza nie może być tak tania jak praca inteligentnych maszyn. W efekcie, za mniej więcej 40 lat 5 proc. ludzkiej siły roboczej - twierdzi Rifkin - zaspokoi całe światowe zapotrzebowanie na dobra i usługi. Trzeba się spodziewać ogromnych napięć światowych, gdy praca i produkcja zaczną znikać z takich krajów, jak Chiny, Indie, Meksyk, kiedy za kilka lat najtańsza siła robocza okaże się droższa od pracy automatów.

Mówi też Rifkin:

kapitalizm wspaniale mobilizuje ludzką energię, pomysłowość, zapobiegliwość. Ale ma też słabą stronę - nie potrafi dzielić bogactwa, jakie wytwarza. [...] Nikomu jeszcze nie udało się skutecznie przekonać kapitalistów, że ich „koszty pracy" to siła nabywcza, bo pracownicy są także konsumentami i inwestorami ${ }^{45}$.

Im bardziej kapitaliści ograniczą koszty, tym mniejszy będzie popyt na ich własną produkcję - powtarza Ryfkin starą tezę Keynesa. Nędzarze nie tworzą popytu, a kiedy nie ma popytu, nie ma i zysku. Świat nie przetrwa 95 proc. bezrobocia. Stąd prognoza Ryfkina ma charakter teoretyczny i ostrzegawczy.

$\mathrm{W}$ rezultacie przy nasilającym się problemie bezrobocia niepodjęcie działania w celu rozwiązania go grozi nasileniem się układów mafijnych, złodziejstwem, rozbojami, rewolucjami, niepokojami społecznymi.

Mafia już dziś - pisał autor pod koniec lat 90. - w wielu krajach zatrudnia więcej ludzi niż sfera budżetowa. A gdzie zaczyna się szara i czarna gospodarka, tam kończą się poważne inwestycje. Czytamy:

Ale ci młodzi ludzie, których nie potrafi wchłonąć ani gospodarka, ani budżetówka, nie muszą iść do mafii. Mogą mieć

${ }^{45}$ Globalny fajrant..., dz. cyt. 
jeszcze jedno legalne źródło utrzymania. To trzeci sektor - kościoły, organizacje sportowe, instytucje samopomocowe, kulturalne, samorządowe, sąsiedzkie, edukacyjne, samokształceniowe, mniejszościowe. Mogą one mieć wielkie znaczenie $\mathrm{w}$ walce $\mathrm{z}$ bezrobociem. One wszystkie tworzą cenne wartości społeczne, podnoszą jakość życia, ale niczego nie sprzedają, a więc nie konkurują z sektorem komercyjnym. Poza tym - i to jest najważniejsze - wykonują pracę, której nie mogą wykonać maszyny ${ }^{46}$.

Ryfkin, jak widzimy, upatruje szansę w trzecim sektorze. Wyjaśnia:

Inteligentna maszyna może kopać doły, wytwarzać produkty, może nimi handlować, może nawet uczyć ludzi matematyki. Ale maszyna nie odprawi mszy św., nie zaopiekuje się dziećmi, nie poprowadzi zawodów sportowych. Trzeci sektor tworzy kapitał społeczny, który być może będzie najważniejszym kapitałem XXI w. To tam będzie najważniejszy rynek pracy w tym stuleciu ${ }^{47}$.

Ale skąd wziąć pieniądze na trzeci sektor? Potrzebne są podatki. Ryfkin jest zdania, że trzeba znieść podatki od pracy, zmniejszyć czas pracy w pierwszym i drugim sektorze, a wprowadzić podatki od wzrostu wydajności, co z pewnością nie spodoba się przedsiębiorcom. Jednak, mówi Rifkin:

To musi kosztować. Na rzecz trzeciego sektora trzeba się opodatkować. Ale lepiej płacić legalne podatki na rzecz trzeciego sektora niż nielegalne na rzecz czwartego. Lepiej płacić za tworzenie kultury niż za pistolety mafiosów i policjantów.

${ }^{46}$ Globalny fajrant..., dz. cyt.

${ }^{47}$ Globalny fajrant..., dz. cyt. 
Taniej jest budować, a potem utrzymywać boiska i domy kultury niż więzienia i komisariaty ${ }^{48}$.

Alternatywą jest nie tylko mafia, ale także fundamentaliści, szowiniści, populiści, ekstremiści z lewicy albo prawicy. Społeczeństwo obywatelskie ich marginalizuje, natomiast zagubione, samotne jednostki chętnie szukają u nich oparcia, poczucia tożsamości, bezpieczeństwa i prawdy o świecie. Taka jest cena próżni społecznej.

Nie przesądzajmy, ile racji mają Rifkin, Cowen, Stiglitz i wielu innych ekonomistów, przeciwników takiego modelu zmiany cywilizacyjnej, która naruszyła podstawy okupionego krwią kompromisu welefare state i pozwoliła na tryumf egoizmu nie więcej niż 10 proc. najlepiej sytuowanych nad 90 proc. pozostałych mieszkańców naszej planety. Faktem jest, że o skutkach takiej ekonomii poucza nas historia. Wojny światowe, rewolucje, Holokaust i gułagi, nędza i zbrodnie, mafia i niezliczone ofiary wśród najsłabszych były skutkiem podobnego egoizmu w przeszłości. Nic dziwnego, że po drugiej stronie barykady stoją socjaliści, którzy jeśli nie wzywają do rewolucji, to w każdym razie upominają się o ekonomię, która bierze pod uwagę potrzeby proletariatu, ludzi pracy (dziś bardziej chyba - klasy średniej). Ekonomiści tej orientacji budują koncepcję gospodarki, której nieobca jest idea sprawiedliwości społecznej lub równości.

Tutaj otwiera się przestrzeń dla katolickiej nauki społecznej. Prekariat i inne dotkliwe skutki wielkiej zmiany cywilizacyjnej nie stają się na zasadzie „deus ex machina”. To nie jest tak, że wzrost dochodów najbogatszych i ubożenie najbiedniejszych jest nieuniknione niczym fatum, jak stara się o tym przekonywać wielu ekonomistów, polityków i dziennikarzy. Jest to kwestia wyboru wartości i wizji społeczeństwa oraz gospodarki. Ową przestrzenią dla katolickiej nauki społecznej jest badanie mechanizmów

${ }^{48}$ Globalny fajrant..., dz. cyt. 
i ukazywanie ich skutków zagrażających dobru człowieka i negujących podstawowe wartości moralne. Zapewne tak zorientowane nauki społeczne także mogłyby być polem poszukiwania nowych konceptów ekonomicznych, politycznych i społecznych, dla których ważna jest nie bogata mniejszość ani biedna większość, ale człowiek i jego dobro, a także ład społeczny regulowany przez zasadę miłości bliźniego. 